\title{
中空層を有する建築物の周辺気流 WIND TUNNEL EXPERIMENTS FOR AIR FLOW AROUND BUILDINGS WITH VOID SPACE
}

\author{
黒谷靖 雄*, 関根 毅** \\ Yasuo KUROTANI and Takeshi SEKINE
}

\begin{abstract}
Wind tunnel experiments were conducted to study the relation between the air flow and the shape of buildings, concentrating on the location of the void space through which air can pass.

The strong wind region near the ground becomes minimum when the distance from the ground to the bottom of the void space is nearly equal to the building width, in case that the building height is 2 to 5 times its width. As the location comes near the ground, the strong wind region increases rapidly.
\end{abstract}

Keywords : wind tunnel test, air flow around buildings, wind disaster, strong wind, void, pilotis[Fr.]

風洞実験, 建築物周辺気流, 風害, 強風, 中空, ピロティ

\section{1. 序}

高層建築物に風が作用すると，その周辺にはその建築 物の建設以前より風速が増加する領域と，風速が低減す る領域が生じることは，周知の事実である。特に，地表 面近傍に生じる風速增加域では，物の飛散，歩行障害な ビが生じ，風速低減域では換気・通風の悪化が生じる。 したがって, 建築物の基本的形状とその周辺気流の関連 については，既に多くの資料 ${ }^{1133}$ 蓄積されている。さ らに, 地表面近傍の風速增加域を低減させる試みとして, 防風フェンスの設置 ${ }^{4)}$ のかにも，七ットバック5)，壁 面の傾斜化 ${ }^{6)}$, コーナーカット ${ }^{7)-10)}$ ，および中空層の設

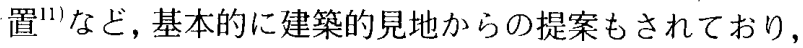
いずれもその効果が認められている。

本研究は，建築物の建設に伴い発生する風害の抑制を 基本的に建築的見地から目指す一連の研究 ${ }^{61,7)}$ の一環を なすものであり，中空層を有する建築物について，中空 層の設置位置とその周辺気流の関連を 3 次元的に明らか にすることを目的として実施した風洞模型実験の結果を 報告するものである。内容的には既報”之関連するが， 既報"がアスペクト比が 2 の矩形建築物を対象としてい るのに対し，本研究においては，アスペクト比が $2 \sim 5$ の矩形建築物を対象としている。

なお，建築物に中空層を設け，中空層の内部を生活空 間亡する状況では，中空層内部の気流性状が重要な問題
となる。そのため，地表面に接して中空層を設け，ピロ ティ形式とした場合のピロティ内部の気流性状 ${ }^{22-14)}$, については，既に資料が蓄積されている。本研究におい ては，建築物周辺の気流性状に焦点を絞り，風害の抑制 に有効な中空層の設置位置を考察しているが，中空層内 部の気流性状に関しても若干の考察を加えている。

2. 記 号
$W:$ 模型幅 $(40 \mathrm{~mm}$ 一定 $)$
$D ：$ 模型奥行 $(40 \mathrm{~mm}$ 一定 $)$
$H$ : 模型高さ $\left(H_{0}\right.$ : 基準高さ $\left.80 \mathrm{~mm}\right)$
$H_{s}:$ 模型風上側の気流の淀み点の高さ
$H_{v}:$ 中空層の中心高さ
$T_{v}:$ 中空層の厚さ $(1 / 8 H$ 一定 $)$
$\delta:$ 境界層厚さ（平均風速が境界層上空風速の $99 \%$ に達する高さ)
$1 / n:$ へき指数
$\lambda_{p}:$ スペクトルスケール
$U_{\infty}$ : 風洞基準風速 $(X=0, Y=0, Z=600 \mathrm{~mm}$ の平均風速, $8 \mathrm{~m} / \mathrm{s}$ 一定)
$U_{Z}:$ 高さ $Z$ における平均風速
$U_{H}:$ 模型高さ $H$ における平均風速
$U:$ 模型周辺の平均風速
$U_{s}: U$ に対応する位置での風洞気流平均風速

* 米子工業高等専門学校建築学科 助教授 $\cdot$ 工博

** 広島大学工学部 教授・工博
Assoc. Prof., Dept. of Architecture, Yonago National College of Technology, Dr. Eng.

Prof., Faculty of Engineering, Hiroshima Univ., Dr. Eng. 
$S_{X}$ : 模型設置に伴う平均風速の変化比 $U / U_{S}$ が $X \%$ 以上となる領域の面積

$\sqrt{\overline{u^{2}}} / U:$ 乱れの強さ

\section{3. 実験方法}

1）風洞：実験に用いた風洞は，米子工業高等専門学校 建築学科所属のエッフェル型吹出式境界層風洞である。 本風洞の測定部断面は， $1.4 \times 0.8 \mathrm{~m}$ であり，測定部の 概要は図一1に示すとおりである。便宜上， $X Y Z$ 座表 系を同図に示すように設定する。乱流境界層の作製に当 たっては，平均風速の鉛直分布（後述）が，べき指数 $1 / 3$ の指数法則に従うことを一応の目標とし，図一 1 に 示すように，測定部の風上側に $40 \times 40 \times 20 \mathrm{~mm}$ の小ラ フネスと, $80 \times 80 \times 40 \mathrm{~mm}$ の大ラフネス，および， 10 $\times 10 \mathrm{~mm}$ の 2 次元ラフネスを試行錯誤的に配列した。 なお,図中の大ラフネスの内でアミカケ表示した部分は, 高さを $80 \mathrm{~mm}$ とした部分である。この部分は左右非対
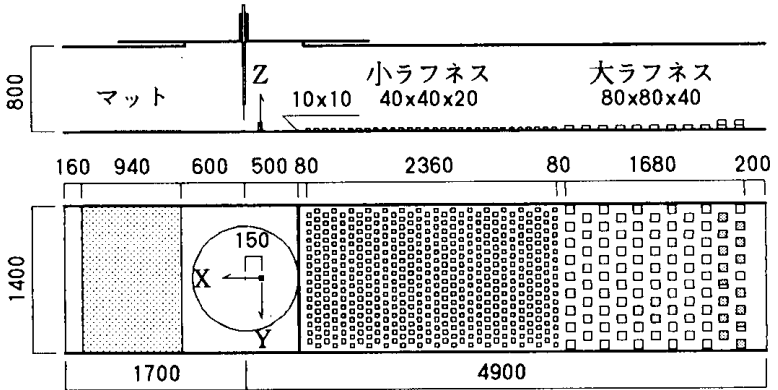

図-1 風洞測定部の概要
称であるが，これは風洞気流の水平分布がより平坦にな るよう試行錯誤した結果である。 $U_{\infty}$ は， $8 \mathrm{~m} / \mathrm{s}$ 一定で ある。

2）模型：実験に用いた模型は，表一1に示す 24 種の 中空層を有する模型と，表一 2 に示す 13 種の矩形模型 であり，いずれの模型も幅 $W 40 \times$ 奥行 D $40 \mathrm{~mm}$ 一定 である。中空層を有する模型は，表一1に示すように， アスペクト比 $(H / W)$ により 4 つのシリーズに分類さ れる。中空層の厚さ $T_{v}$ は，模型高さ $H$ の $1 / 8$ 一定で ある。，中空層内部の支柱は，表一1に示すように 3 本で あり，風洞気流に対して左右非対称である。これは，中 空層内部の気流性状をできる限り支柱の影響を避けて測 定するためである。このことにより, 厳密には, 模型周 辺の流机場は左右の対称性を欠くことになるが，支柱に よる影響は風下側の狭い範囲に限定されている(後述) ため，全体の流れ場に与える影響は小さい。なお，中空 層を有しない 13 種の矩形模型は, 中空層の設置に伴う 周辺気流の変化を考察するための対照標準として用い る。風洞断面に対する模型の見付け面積の比（閉塞率） の最大值は，H 200 の模型において $0.71 \%$ であり，模 型による風洞気流の閉塞効果は問題とならない ${ }^{15)}$ 。各模 型とも，模型の中央が風洞地面盤上 $(X=0, Y=0)$ で 一致するように設置した。

3）模型周辺気流測定領域求よび測定点：模型周辺気流 の測定は， $X$ 方向には模型の中心を基準として風上側 に $3 D$, 風下側に $6 D, Y$ 方向には模型の中央で流れ場
表一1 中空層模型

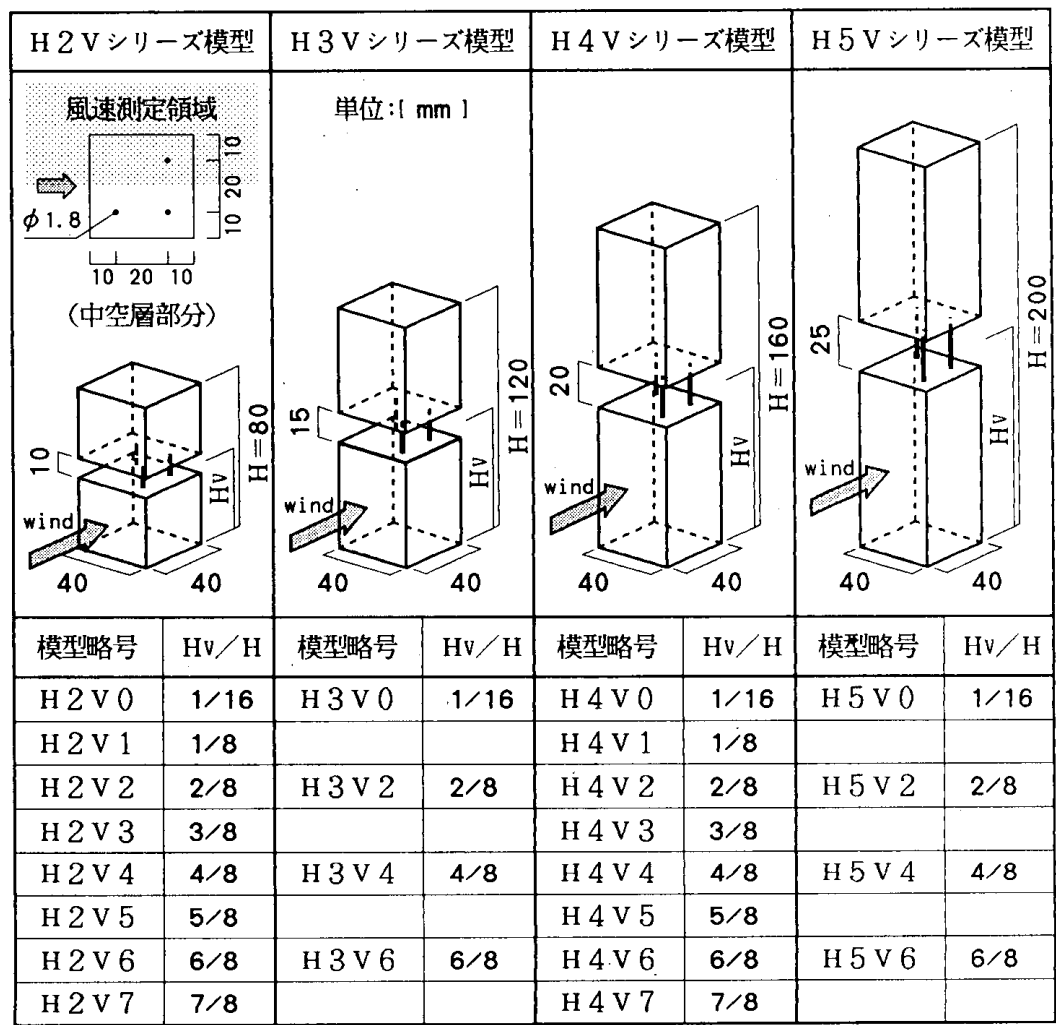

表一2 矩形模型

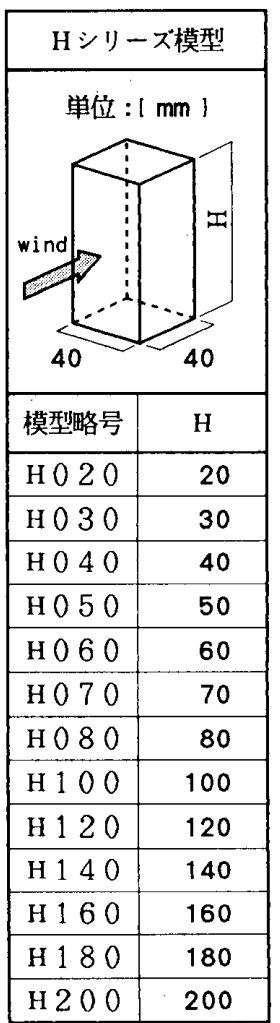


がほぼ左右対称であるとして，0～ $3 W($ 一部 $4 W$ ), $Z$ 方向には, $0.2 W \sim H+W$ の範囲で行った。測定点は, 模型の周辺に 3 次元的に設定されており，表一1に示す $\mathrm{H} 4 \mathrm{~V}, \mathrm{H} 5 \mathrm{~V}$ シリーズの模型については，中空層の内部 にも設定されている。测定点の総数は模型により異なる が，中空層を有する模型については 2063４217点であ り, 矩形模型については 821〜3433 点である。模型近 傍における最小测定点間隔は, 模型幅 $W$ の $1 / 8$ である。 4) 風速・風向测定および解析装置：風速の測定には, 定温度型熱線風速計（日本科学工業製，温度補償ユニッ 卜付）を用い，センサーはタングステン $(5 \mu \phi)$ 製 I 型 熱線プローブを横㯰き（熱線部分が鉛直方向）で使用し た。本風速测定方法は, 風速測定時鉛直面内において強 い指向特性があるため, 模型の風上側と風下側の壁面近 傍のように, 下降気流もしくは上昇気流が顕著な場所で は大きな誤差を生じるが, 風向変動が小さい模型側方の corner-flow 領域での点差は小さい7”。また, 地表面近傍 の wake 領域においては, 現在各方面で多用されている 無指向性のサーミス夕風速計との対応は良好であるが, ベクトル演算形式の風速測定でないことに伴う誤差は大 きい?。したがって, 結果の考察においては, 模型の風 上側および風下側の wake 領域の風速については定性的 扱いをすることとする。風向は，ほぐした絹系（長さ約 $10 \mathrm{~mm}$ ) を用いて，タフト・スティック法で测定した。 模型周辺気流の風速解析は, パーソナル・コンピュータ (日本電気製 $\mathrm{PC}-8801)$ に A/D 変換モジュール（ネオ ローグ電子製 $\mathrm{PNC}-1209)$ を組み込み, 風速の実質分 解能約 $0.005 \mathrm{~m} / \mathrm{s}, \mathrm{A} / \mathrm{D}$ 変換周期 $10 \mathrm{~ms}$, サンプリング 数 2000 点で行った。

\section{4. 風洞気流性状}

実験に用いた風洞気流の気流性状を，図一2に示す。 図一2(a) は，模型設置位置 $(X=0, Y=0)$ における 風洞気流の平均風速と, 乱強さの鉛直分布を示して いる。同図によ机ば，平均風速の鉛直分布は， $Z=25$ $300 \mathrm{~mm}\left(Z / H_{0} \fallingdotseq 0.3\right.$ 3.8）の範囲内で，おおむねべき 指数 $1 / 3$ の指数法則に従っていることが明らかである。 平均風速の鉛直分布は， $X=0$ 上り風上側では，さらに 下層までべき指数 $1 / 3$ の指数法則に従うが, 模型周辺気 流の測定領域内での気流性状の安定性を考慮し， $X=0$ を模型設置の基準点とした。境界層の厚さ $\delta$ は, 約 300 $\mathrm{mm}$ であり, 乱れの強さは, 高さ $Z=80 \mathrm{~mm}\left(Z / H_{0}=1\right)$ において約 $20 \%$ である。

図一2(b) は，模型設置位置 $(X=0, Y=0)$ におけ るスペクトルスケール $\lambda_{p}$ の鉛直分布を示している。ス ペクトルスケールの算出においては, $100 \mathrm{~Hz}$ のローパ スフィルタを用い, A/D 変換周期 $5 \mathrm{ms,} \mathrm{サンプリング}$ 数 2048 点でサンプリングし, MEM (Burg) 法により

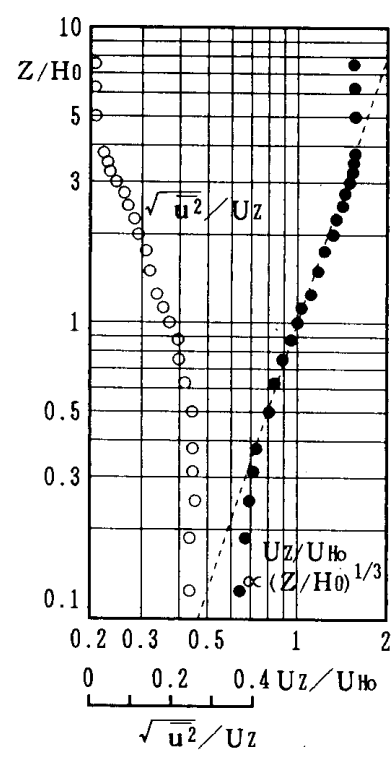

(a) 平均風速 ·乱扎の強さ

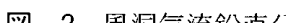

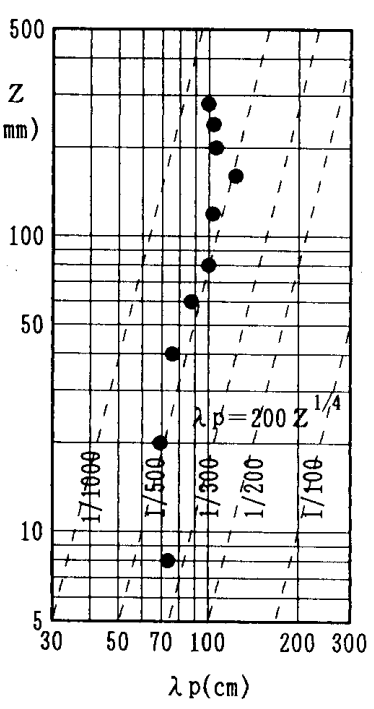

（b）スペクトルスケール $(X=0, \quad Y=0)$
スペクトルを求めた。同図によれば，スペクトルスケー ル $\lambda_{p}$ は, $Z=20 \sim 160 \mathrm{~mm}$ まで, ほぼ高さ $Z$ の $1 / 4$ 乗 に比例して増加している。実測值として仮に,

$$
\lambda_{p}=200 Z^{1 / 4} \text { (Berman) }
$$

を想定し ${ }^{16)}$ ，縮率をパラメータとして表示すれば，図中 の破線で示すようになる。これより，本風洞測定部には， 実物の1/500１/600のスペクトルスケールが再現され たことになる。

以上のことより，この風洞気流は，平均風速と乱れの 強さおよびスペクトルスケールの鈶直分布に関して，市 街地上空の大気境界層を，おおむ的確にシミュレート しているといえる。ただし，本実験においては，縮率を $1 / 600$ とすると境界層の再現高さ $\delta$ は $180 \mathrm{~m}$ 程度であ り, 高さ $H$ が $180 \mathrm{~mm}$ 亡 $200 \mathrm{~mm}$ の模型の $\delta / H$ は, そ れぞれ約 1.7 と 1.5 である点に注意を要する ${ }^{17) 。 ~}$

\section{5. 実験結果}

\section{1 高さの異なる矩形模型の周辺気流}

表一 2 に示す幅 $W 40 \times$ 奥行 D $40 \mathrm{~mm}$ が一定で, 高さ $H$ のみが異なる矩形模型 13 種について，その周辺気流 を 3 次元的に测定した。結果の一部を図一 3 と図一 4 に 示す。

図一 3 は，模型周辺気流の平均風速 $U$ を同一点の風 洞気流平均風速 $U_{S}$ で基準化した風速比，すなわち，模 型設置に伴う平均風速の変化比 $U / U_{s}$ の分布を表して いる。同図には, $Z / W=0.2(Z=8 \mathrm{~mm})$ の $X Y$ 水平 面と, 模型中央である $Y=0$ の $X Z$ 鉛直面, および, そ れと直交する $X=-3 D$ $Y Z$ 鉛直面に, $10 \%$ 間隔の 等值線亡, 各面内の测定点 (図中・印) を, さらに, $D$ 間隔ごとの $Y Z$ 鉛直面に $90 \%$ と $110 \%$ の等値線を表 示している。 


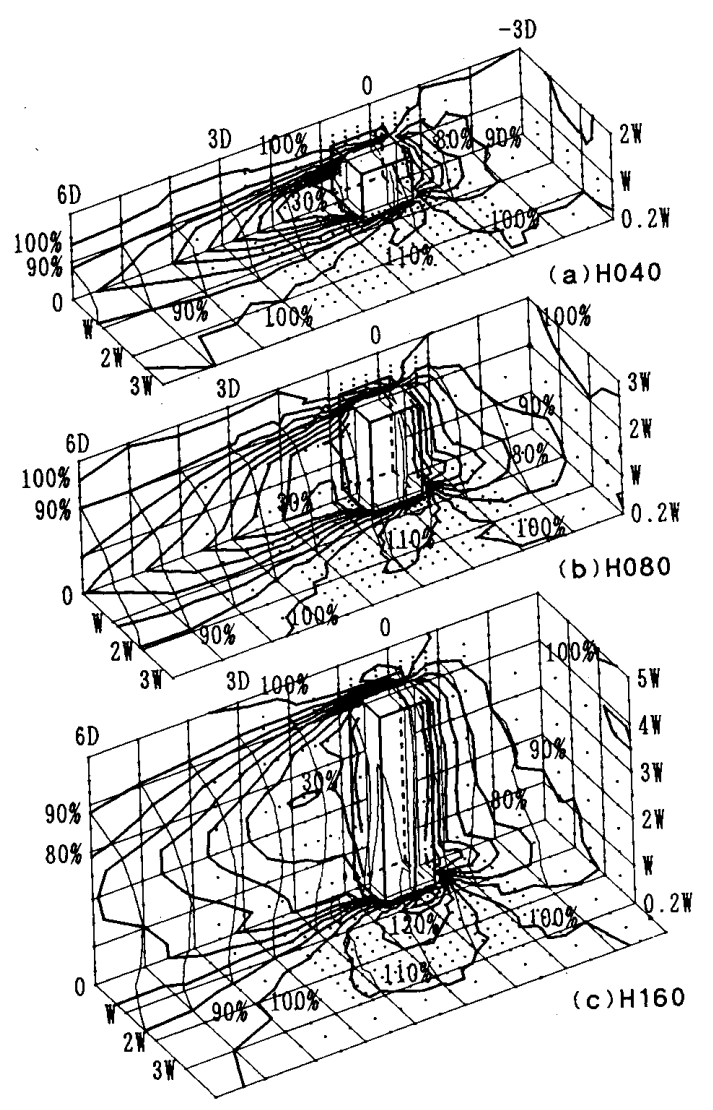

图一-3 矩形模型の周辺気流分布 $\left(U / U_{s}\right)$

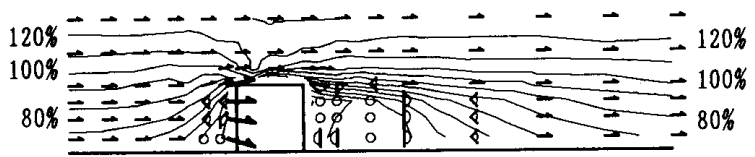

(a) $\mathrm{HO} 40$

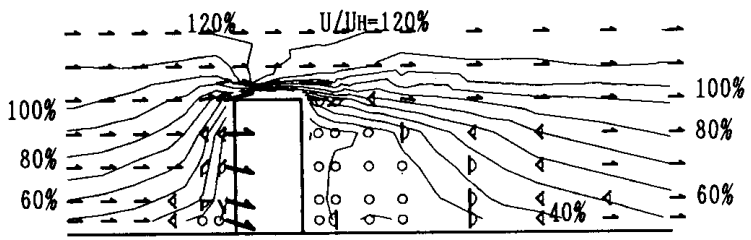

(b) $\mathrm{H} 080$

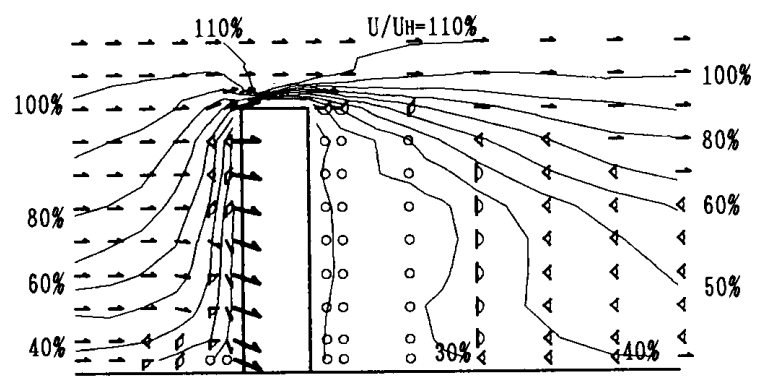

(c) $\mathrm{H} 160$

図一4 矩形模型の風向亡 $U / U_{H}$ の分布

図一 4 は，模型中央を通る $X Z$ 鉛直面内の風向（図中 細矢印) と，模型周辺気流の平均風速 $U$ を模型設置中 心位置における模型高さの風洞気流平均風速 $U_{H}$ で基準 化した風速比 $U / U_{H}$ の分布, および模型の風上側隅角 部近傍 $(X=-25, Y=25)$ における風向（図中太矢印） を表している。なお，風向の表示で円形あるいは扇形の
表示は，その位置でタフトが回転もしくは扇形の範囲で 激しく振れたことを意味している。

これらの実験結果から得られた知見の内，(1)模型高さ 之風速変化比 $U / U_{s}$ の最大值との関係, (2)模型高さ之 模型側方の風速増加域面積との関係については，すでに 既報 で報告しており，さらに，中空層を有する模型に 関する結果とともに図示するので，ここでは結果の要約 のみを記す。

(1) 風速增加域の平均風速変化比 $U / U_{S}$ の最大値は, 高さ $H$ にほぼ比例して増加する。

(2) 模型側方の風速増加域の面積は, 高さ $H$ の増加に 伴い二次関数的に増大する。なお, 地表面に近いほざ風 速増加域の面積増加が顕著である。

模型風上側の気流の淀み点は, 厳密には壁面風圧の測 定により決定されるが，簡便的に，模型の中央を通る $X Z$ 鉛直面内，および模型の風上側隅角部近傍の風向を もとに，模型風上側の気流の淀み点の高さ $H_{s}$ を求めた。 その結果は, 中空層を有する模型に関する結果とともに 図一7に示す。これによれば,・模型のアスペクト比が 1 ～3の範囲では, アスペクト比の増加に伴い気流の淀み 点の相対位置 $H_{S} / H$ は上昇するが，アスペクト比が 3 5 では，ほぼ一定 $\left(H_{s} / H=0.83\right)$ となることが明らか である。

5.2 中空層の設置位置とその周辺気流の関係

表一1に示す中空層を有する模型 24 種について，そ の周辺気流を 3 次元的に測定した。それらの結果の内,

$\mathrm{H} 4 \mathrm{~V}$ シリーズ模型に関する結果の一部を図一 5 と図一 6 に示す。なお，これらの図の表現方法は，図一3および 図一4 と同様である。これらによれば，中空層の設置に より，模型の風上側と風下側の静圧差に起因する強風が 中空層内部を通り抜けるため, 特に中空層周辺の気流が 大きく変化していることが明らかである。また，中空層 を地表面に接して設け，ピロティ形式とした場合には地 表面近傍の風速増加域がかなり拡大し，中空層を模型の 上部に設置した場合にはいくぶん縮小していることが特 徵的である。なお，一部分がピロティとなっている板状 建築物模型の周辺気流については, 防風垣による強風遮

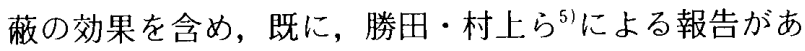
る。

\section{2 .1 気流の淀み点の位置}

詳細に中空層の設置位置とその周辺気流の関係を検討 するための基礎資料として，まず，一般に地表面近傍の 風速増加域の広がり之関連が深いとされている模型風上 側の気流の淀み点の高さ $H_{s}$ と, 中空層の設置位置との 関係を明らかにした。図一7は，H4Vシリーズの模型 に関して，その結果をま之めたものである。なお，同図 には，参考のため，中空層を有しない矩形模型に関する 結果も併記している。同図に示すように, 中空層の設置 

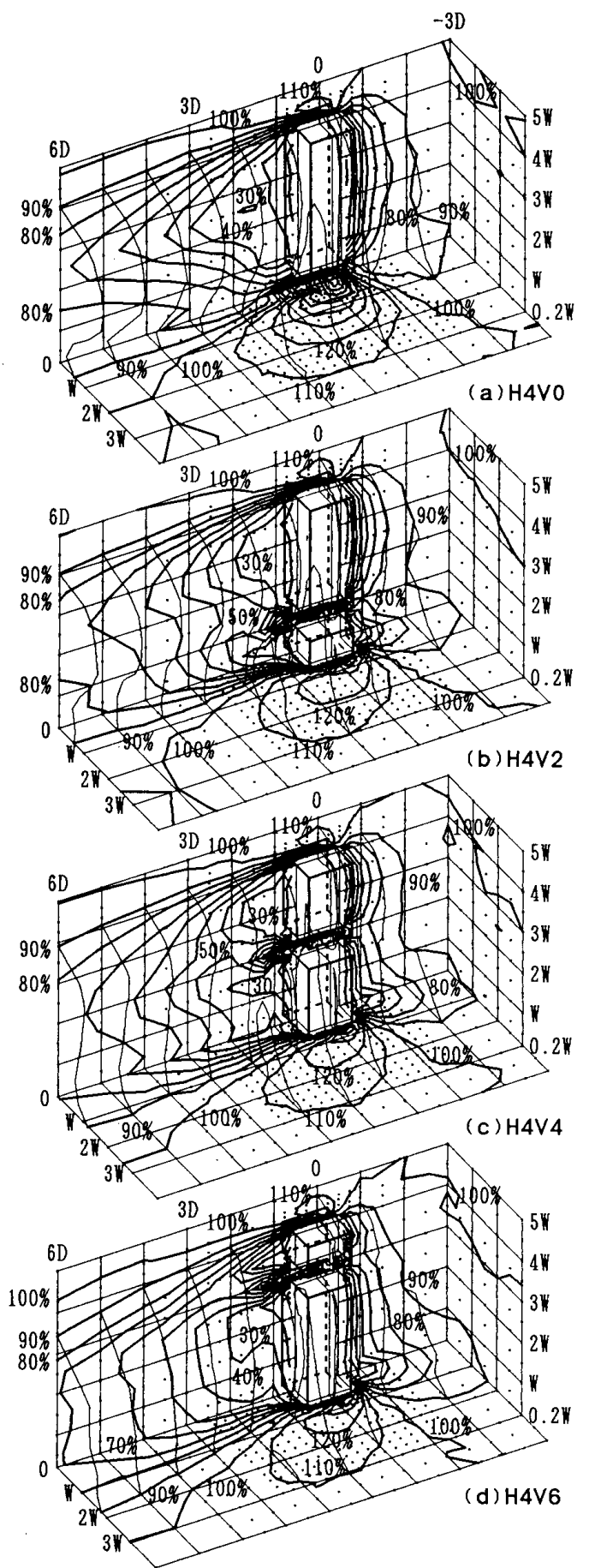

図一5 H4Vシリーズ模型の周辺気流分布 $\left(U / U_{s}\right)$

に伴い，模型が上下に分割された場合，中空層の下部に も気流の淀み点の存在が確認される。また，中空層を元 来の気流の淀み点より下方に設置した場合, 中空層より 上部の気流の淀み点は，中空層を有しない状態とほぼ同 一の高さに位置しており, 中空層より下部の気流の淀み 点は, 中空層の近くに位置していることが明らかである。 このことにより，中空層が模型の下層部に設置された場 合（ピロティ形式の場合を除き），地表面近傍に直接的 に作用する模型風上側の下降気流は極端に娍少すること が明らかである。実際, 図一5において, 模型風上側の 地表面近傍における風速低減域の広がりは, 中空層を下

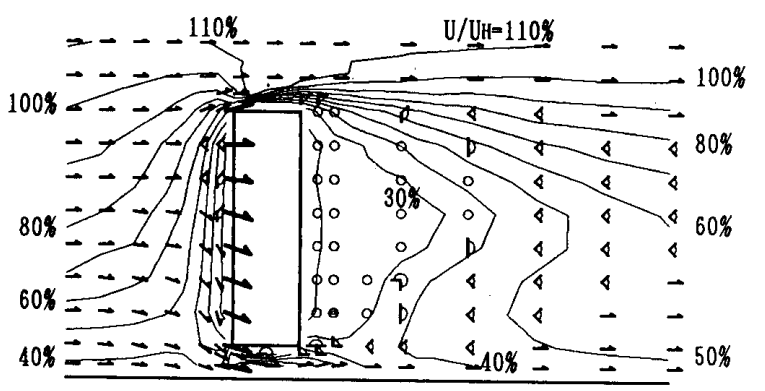

(a) $\mathrm{H} 4 \mathrm{~V} 0$

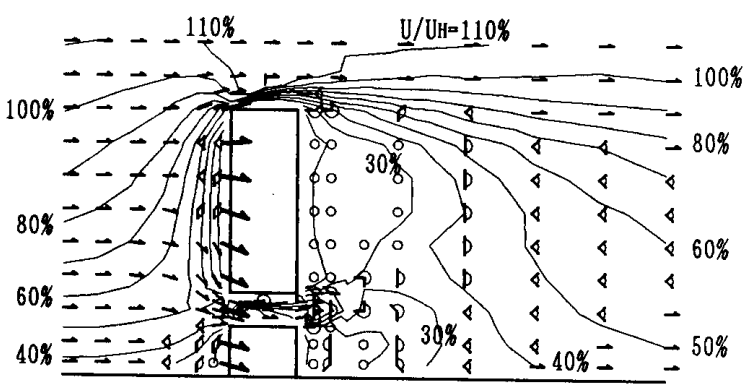

(b) $\mathrm{H} 4 \mathrm{~V} 2$

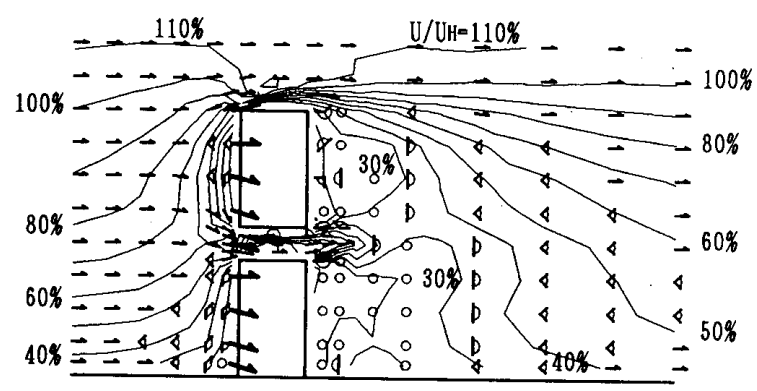

(c) $\mathrm{H} 4 \mathrm{~V} 4$

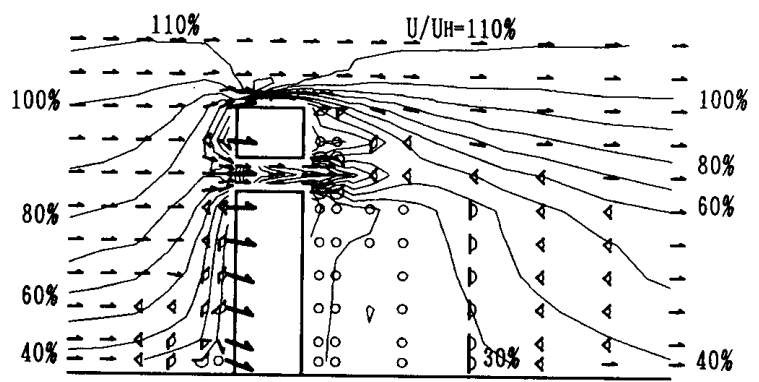

(d) $\mathrm{H} 4 \mathrm{~V} 6$

図一- $\mathrm{H} 4 \mathrm{~V}$ シリーズ模型の風向よ $U / U_{H}$ の分布

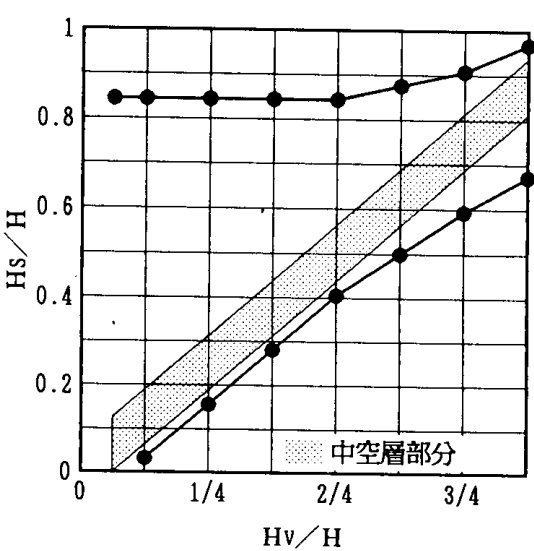

（a）中空層模型 $(\mathrm{H} / \mathrm{W}=4)$

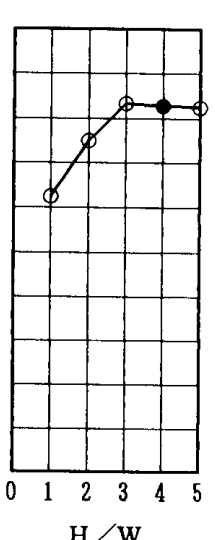

(b) 矩形模型
図一7 中空層の設置位置と気流淀み点高さの関係 
層部に設置するほど小さくなっている。さらに, 中空層 の下部に位置する気流の淀み点の存在は, 模型側方の気 流に影響を与えているが，このことについては模型周辺 の風速増加域との関連から5.2.3節で後述する。

なお，気流の淀み点の位置に関しては，結果の表示を 省略している他のシリーズの模型についても同様の結果 が得られているが，中空層より下方に位置する気流の淀 み点の存在は, 主として中空層の相対的厚さ $T_{v} / H$ に 依存した現象であることは言うまでもない。

\subsection{2 中空層内部の気流性状}

さらに詳紐に中空層の設置位置とその周辺気流の関係 を検討するための基礎資料として, 次に中空層内部を通 り抜ける気流の性状について述べる。図一6によれば, 中空層付近の気流の流れのパターンは, 中空層の設置位 置により異なる。まず, 図一6(a)〜 (c) に示すように, 中空層を元来の気流の淀み点より下方に設置した場合,

主として，模型風上側の下降気流が下向きのベクトルを 持って中空層に流れ込むため, 中空層の上部前縁で気流 のはく離が生じる。そのため, 中空層内部の上部空間は wake 領域となり，下部空間は縮流に伴い強風領域とな る。なお,ピロティ内部の平均風速の鉛直分布に関して は, すでにPenwarden $ら^{(2)}$ と高木ら ${ }^{131}$ による测定例が あり,ピロティ内部の特に下部空間が強風領域になるこ とが明らかにされている。中空層を通り抜けた気流は, 模型の風下側壁面近傍に生じている上昇気流の影響を受 け, 若干上向きのベクトルを持って流れ出し, その後, 急速に模型全体から生じている wake 領域に昖散してい る。一方, 図一6(d) に示すように, 中空層を元来の気 流の淀み点付近に設置した場合, 中空層の風上側に卓越 した気流が存在しないため, 中空層内部にははく離に伴 う大きな wake 領域は存在せず，上下対称の流れが生じ る。また, 中空層を元来の気流の淀み点より上方に設置 した場合（結果の表示をしていないが H 4V7 の模型の 場合), 逆に中空層の下部前縁で気流のはく離が生じ, 中空層内部の下部空間が wake 領域となる。中空層内部 の気流性状をさらに 3 次元的に検討するため, 一例とし て, 図一6(c) に示す模型（H4V4）に関するより詳細 な測定結果を図一 8 に示す。これによれば，中空層の内 部の流れはほぼ 2 次元的な流れであり, 中空層内部の支 柱から生じる影響は, 風下側の狭い範囲に限定されてい ることが明らかである。さらに，同図には図示していな いが，中空層の側面における風向は，鉛直方向には中空

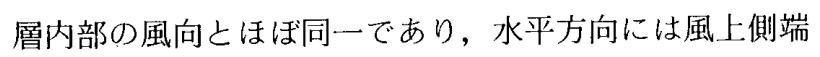
部で $20^{\circ}$ 程度外向きとなるが, 中央部および風下側端部 ではほ上んど0゚となっている。なおこのことは他の 模型についても同様に言える。

次に, 中空層内部を通り抜ける気流を定量的に把握す

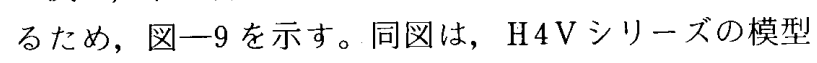

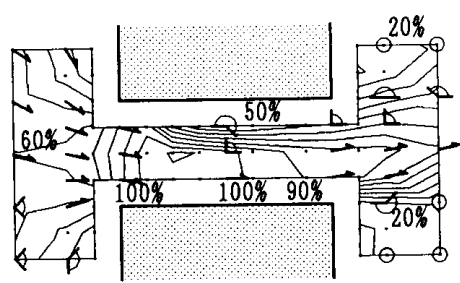

(a) $\mathrm{Y}=0, \mathrm{XZ}$ 平面

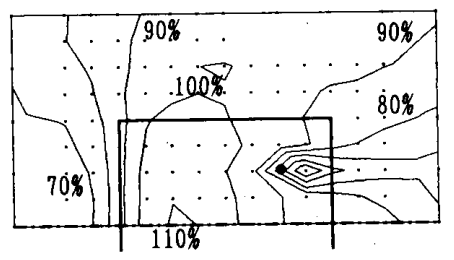

(c) $\mathrm{Z}=80, \mathrm{XY}$ 平面

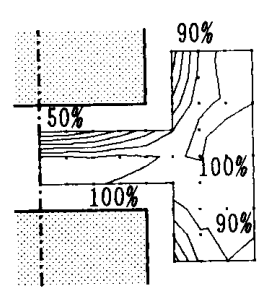

(b) $\mathrm{X}=0, \mathrm{Y} Z$ 平面

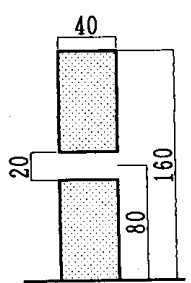

(d) 模型
図一8 中空層内部の風向と $U / U_{H}$ の分布 $(\mathrm{H} 4 \mathrm{~V} 4)$

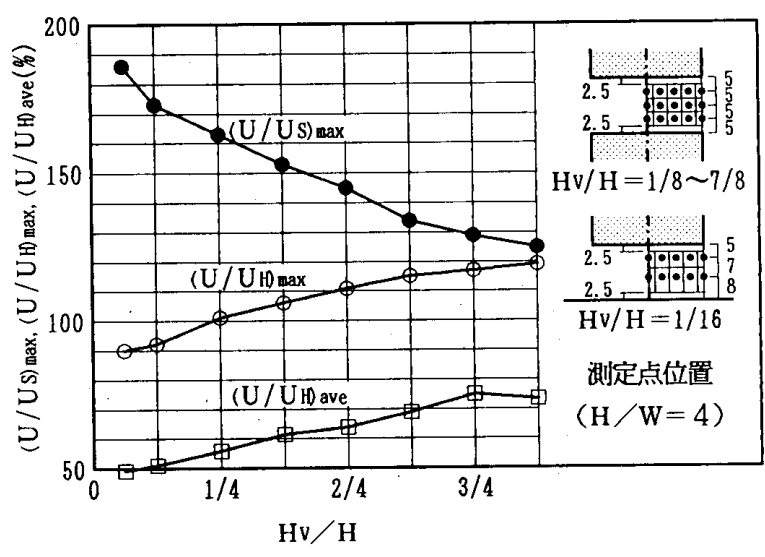

図一9 中空層の設置位置と中空層内部の風速との関係

に関して, 中空層の設置位置 $H_{V} / H$ と中空層内部の平 均風速変化比の最大值 $\left(U / U_{S}\right)_{\max }$, および平均風速比 $U / U_{H}$ の最大值 $\left(U / U_{H}\right)_{\max }$ との関係, さらに平均風速比 $U / U_{H}$ の平均值 $\left(U / U_{H}\right)_{\text {ave }}$ との関係を表している。ここ で, $\left(U / U_{S}\right)_{\max }$ と $\left(U / U_{H}\right)_{\max }$ の算出は, 図一 9 と図—8 に・印で示すように, 中空層内部に合計 126 点（ただし， ピロティ形式となった場合 84 点) の測定点を設定し算 出した。また, $\left(U / U_{H}\right)_{\text {ave }}$ の算出は, 図一 9 に示すように, 模型の中央 $(X=0, Y Z$ 平面) に位置する合計 15 点（た だし，ピロティ形式となった場合 10 点）の測定点を用 いて算出した。なお, 平均値の算出は, 図中の測定点を 囲む格子内の面積で重み付けをして行った。図一9によ れば, $\left(U / U_{s}\right)_{\max }$ はピロティ形式とした場合に最大 $(186 \%)$ となるが, $\left(U / U_{H}\right)_{\max }$ は最小 $(90 \%)$ であり， 上部に中空層を設置するほど大きい。また, 中空層を通 り抜ける気流の流量之直接関係する $\left(U / U_{H}\right)_{\text {ave }} も$, おお む权上部に中空層を設置するほゼ大きいが, 厳密には, 元来の気流の淀み点付近に設置した場合に極大となる。 これは，前述のように，この位置では中空層内部に大き な wake 領域が生じていないことに依存している。なお, ピロティ形式とした場合の結果を, 高木ら ${ }^{13}$ の結果と比 
較すると，高木らはアスペクト比 $4 （ W 100 \times H 400 \times$ $D 50 \mathrm{~mm}, T_{v}=20 \mathrm{~mm}$ ，側壁有）の場合，ピロティ中央 部の $\left(U / U_{s}\right)_{\max }$ は, 約 $250 \%$ 程度であるとしており, 本実験の方が小さな値となっている。この原因に関して は，風洞気流の鉛直分布，風洞閉塞率（風洞断面に対す る模型の見付け面積の比), 側壁の有無, ピロティ部分 の相対的厚さ $T_{v} / H, T_{v} / D$ など多くのパラメー夕が両 実験間で異なるため，現時点では何とも言えない。

\section{2 .3 模型周辺の風速増加域}

中空層の設置位置と模型側方の風速增加域との関係を 定量的に把握するため，まず，図一10 と図一11 を示す。 図一10(a)は, $\mathrm{H} 4 \mathrm{~V}$ シリーズの模型に関して, 中空層 の設置位置 $H_{v} / H$ 之平均風速変化此の最大值 $\left(U / U_{s}\right)_{\text {max }}$ との関係を, 地表面からの高さ $Z / W$ をパラメータと して表している。ただし， $\left(U / U_{s}\right)_{\max }$ の算出においては, 矩形模型との比較を考慮し, 中空層内部の領域（厳密に は模型壁面から $5 \mathrm{~mm}$ 末満の領域) の測定値は除いてい る。図一10(b) は, 高さ $H$ のみが異なる矩形模型に関 して, アスペクト比 $H / W$ と $\left(U / U_{s}\right)_{\max }$ との関係を表 している。図中の記号は, 図 (a) の記号と対応しており, 図中の回帰直線の相関係数は, いずれも 0.993 以上であ

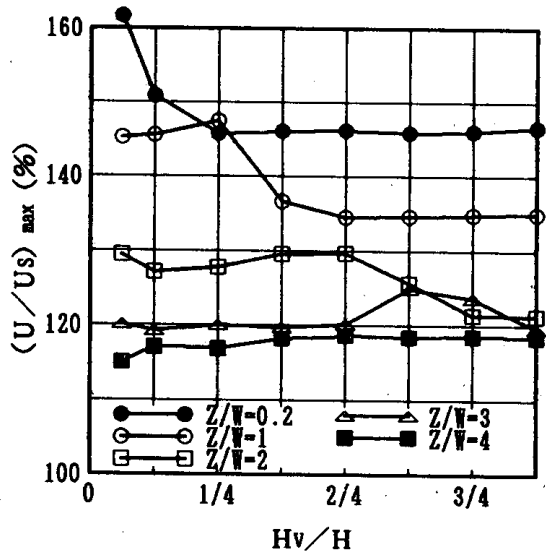

（a）中空層模型 $(\mathrm{H} / \mathrm{W}=4)$

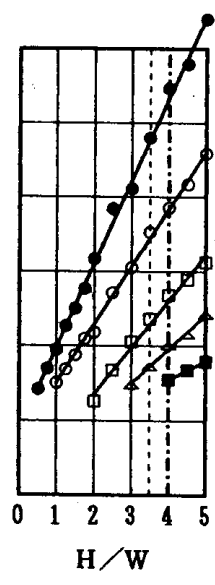

(b) 矩形模型
図一10 中空層の設置位置と $U / U_{s}$ の最大值との関係

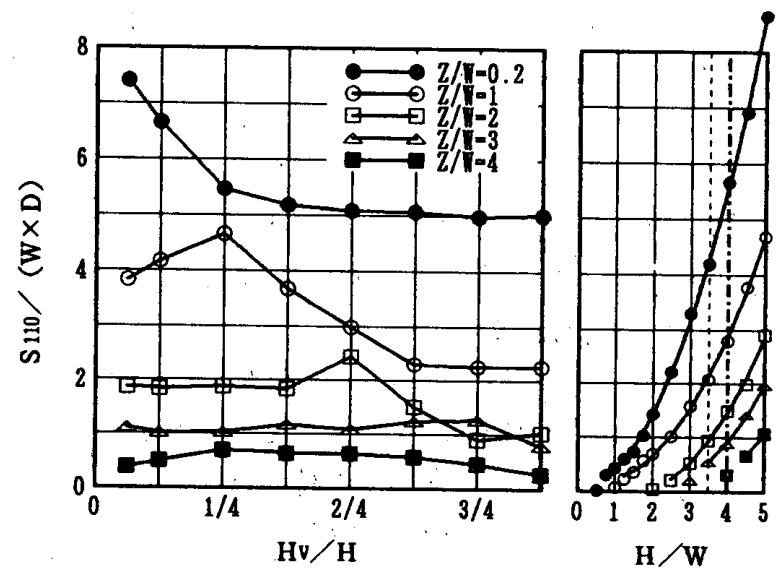

(a) 中空層模型 $(H / W=4)$

(b) 矩形模型

図一11 中空層の設置位置と風速増加域面積との関係 る。なお，図（b)において, $H / W=3.5$ の状態は，中 空層の厚さ $T_{v}$ 分だけ高さの低い矩形模型に対応してい る。図一11 は，図一10 と同様にして，中空層の設置位 置と風速増加域の面積 $S_{110}$ （模型設置に伴う平均風速の 変化比 $U / U_{s}$ が $110 \%$ 以上となる領域の面積）との関 係を表している。ただし, 風速増加域面積の算出におい ては, 矩形模型の風速増加域との比較を考虑し, 中空層 内部の領域（厳密には模型壁面から $5 \mathrm{~mm}$ 以内の領域） の面積は除いている。なお, 図 (b) の回帰曲線は, 最 小自乗法により二次の多項式への当てはめを行って描い たものであり，その相関係数はいずれも 0.998 以上であ る。これらによれば,

(1) ピロティ形式として中空層を設けた場合, 模型周辺 の地表面近傍 $(Z / W=0.2)$ における $\left(U / U_{S}\right)_{\max }$ は, 同 じ高さの矩形模型と比較して約 $9 \%$ 増加し， $S_{110}$ は約 1.3 倍に増大している。

(2) しかしながら，中空層を高さ $H$ の $1 / 4$ 以上の位置 に設けた場合， $\left(U / U_{s}\right)_{\text {max }}$ は同じ高さの矩形模型と比較 して約 $7 \%$ 低減し， $S_{110}$ は約 1 割减少している。なお, $S_{110}$ に関しては，中空層の厚さ分だけ模型の高さを低く するほうがより大きく減少するが， $\left(U / U_{s}\right)_{\max }$ に関して は，中空層を設置したほうが大きく低減する。

(3) 模型側方の空間全域に着目すると，ある高さの水平 面内の $\left(U / U_{s}\right)_{\max }$ および $S_{110}$ は，その水平面と同じ高 さに中空層が設置された場合に最大になるが，その水平 面より上方に中空層が設置された場合より，下方に設置 された場合の方が大きい。たとえば， $\left(U / U_{s}\right)_{\max }$ に関し て言えば， $Z / W=2$ すなわち $Z / H=0.5$ の水平面にお いては, $H_{v} / H=0.5$ の時, $\left(U / U_{s}\right)_{\max }$ は $130 \%$ で最大 となる。そして $H_{v} / H=0.75$ の時 $121 \%$ となり，矩 形模型の場合の $126 \%$ より低減するが, $H_{v} / H=0.25$ の時は $128 \%$ である。なお，これは模型風上側の気流 の淀み点の位置に関連した事象である。すなわち，図一 6 より明らかなように，中空層が元来の気流の淀み点よ り下方に設置された場合には，中空層の上方では風上側 の下降気流が発達し，それに伴い模型の側方に流出する 気流も強い下向きのベクトルを持つが，中空層の下方に は気流の淀み点が位置するため，側方に流出する気流の ベクトルは水平に変わり，上方からの下降気流の影響が 中空層の下方で一旦弱まるためである。'さらに，地表面 近傍においても，この現象により中空層を高さ $H$ の 1/4 以上の位置に設けた場合には風速増加域が縮小し, それより下方に設けた場合には桩大すると考えることが できる。したがって，地表面近傍の風速増加域を低減す るのに有効な中空層の設置位置は, 高さ $H$ を基準とし た相対位置ではなく，地表面からの絶対高さで表される と考えられる。

次に, 中空層の設置高さ $H_{v} / W$ と模型側方の地表面 


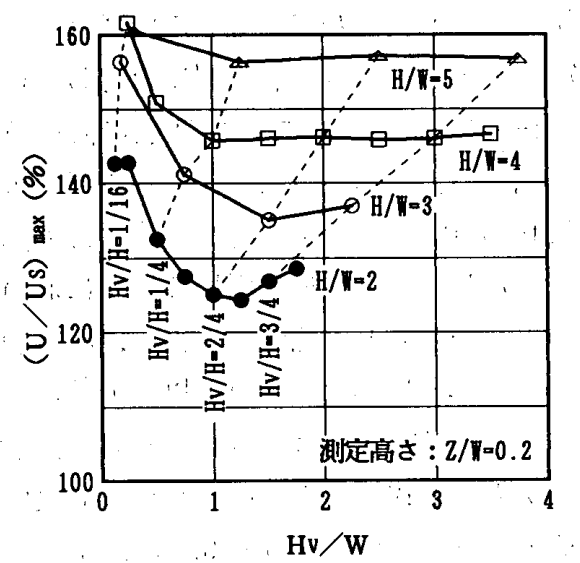

（a）中空層模型 $(H / W=2 \sim 5)$

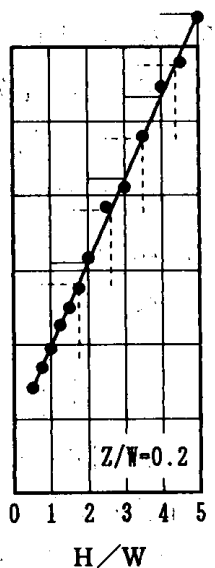

(b) 矩形模型

図一12.中空層の設置高さと $U / U_{s}$ の最大値との関係

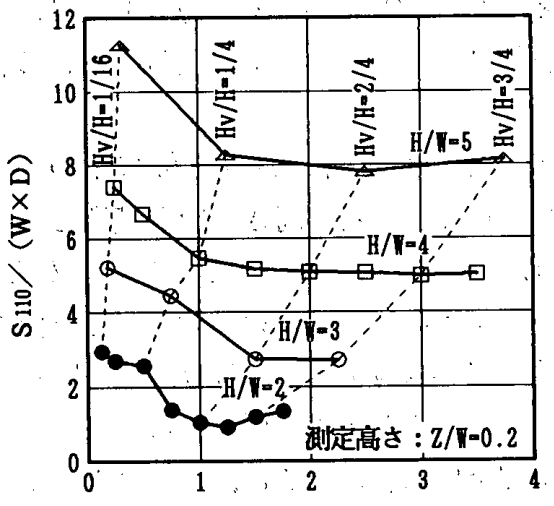

$\mathrm{HV} / \mathrm{W}$

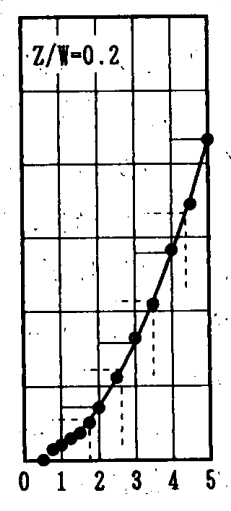

$\mathrm{H} / \mathrm{W}$ (a) 中空屏模型 $(\mathrm{H} / \mathrm{W}=2 \sim 5)$

图一13 中空層の設置高さと風速増加域面積との関係

近傍（ $(Z / W=0.2)$ における風速増加域との関係を， 模型のアスペクト比をパラメータとして, 図一12と図 一13に示す。これらによれば,

(1)!模型のアスペクト比によらず, 模型周辺の地表面近 傍における $\left(U / U_{s}\right)_{\max }$ および $S_{110}$ は，中空層を地表面 に接して設け，ピロティ形式とした場合に最大となる。 ピロティ形式とした場合の $\left(U / U_{s}\right)_{\max }$, 同じ高さの矩 形模型のものと比較し, その増減の程度を矩形模型の高 さの増減に置き換えて表すと，アスペクト比が $2,3,4$, 5 の場合, それぞれ, $1.05 W$ 分の増加, $1.27 W$ の増加, $0.75 W$ の増加, $0.35 W$ 分の娍少と等価であり, アスペ クト比が小さいものほど増加の程度が大きい。 また, ア スペクト比が 4 以上では, $\left(U / U_{s}\right)_{\max }$ はほぼ一定である。 そのため, アスペクト比が 5 の場合には, ピロティを設 けることにより $\left(U / U_{s}\right)_{\max }$ が低減している。同様にして， ピロティ形式として中空層を設置した場合の $S_{110}$ の増 减を, 矩形模型の高さの増減に置き換えて表すと, アス ペクト比が $2,3,4$ の場合，それぞれ，0:89W 分の増加, $0.87 W$. 分の増加, $0.62 W$ 分の増加亡等価であり, $\left(U / U_{s}\right)_{\max }$ と同様，おおむねアスペクト比が小さいもの ほど増加の程度が大きい。

(2)，中空層を適切な位置に設けることにより，模型周辺 の地表面近傍における風速増加域を低減させることがで きる。ここで, 図一 12 と図一 13 において，H/W=3に 関する $H_{V} / W=1$ 付近のデータを $H / W=2$ と 4 の状況 から類推するならば，最大の低減効果が期待できる中空 層の設置位置は, 地表面から中空層の下端までの高さが ほぼ幅 $W$ : と等しい位置であると言える。また，模型の アスペクト此が 4, 5 の場合には, それ以上の高さであ れば, 同程度の低娍効果が期待できる。中空層を最適な 位置に設けた状態では, 模型のアスペクト比にかかわら ず, $\left(U / U_{s}\right)_{\max }$ は約 7-8\% 減少し, その効果を矩形模 型の高さの増減量に置き換えて表すと, 高さを約 $0.6 \mathrm{~W}$ ～0.7W 分低くすることと等価である。なお，中空層の 厚さ $T_{v}$ はアスペクト比が $2,3,4,5$ の場合, それぞれ $0.25 W, 0.375 W, 0.50 W, 0.625 W$ であるので, 中空 層の厚さ当たりの低減効果という点では, アスペクト比 が小さいものほどその低減効果が大きい。同様に， $S_{110} /(W \times D)$ は，模型のアスペクト比にかかわらず, 約 0.5〜0.6 減少している。:これは, アスペクト比が 2, 3, 4,5 の場合，それぞれ高さを $0.41 \mathrm{~W}, 0.23 \mathrm{~W}, 0.22 \mathrm{~W}$, $0.14 W$ 分だけ低くすることと等価である。したがって， アスペクト比が 2 の場合は, 中空層の厚さ $\left(T_{V}=0.25 \mathrm{~W}\right)$ 分だけ高さを低くするよりさらに大きな低減効果が期待 できるが，アスペクト比が 3 以上の場合は，高さを低く するほうが効果が大きい。

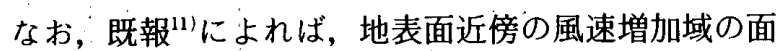
積と中空層内部を通り抜ける気流の流量との間には, 一 次回㷌により負の強い相関（相関係数 0.94 以上）が認 められたが, 今回の実験で中空層内部の平均風速を測定 したアスペクト比が 4 と 5 の模型については，相関係数 はそれぞれ，0.84と0.85であり，既報で認められたほ どの強い相関は認められない。

\section{6. 結 語}

市街地上空の大気境界層をシミュレートした乱流境界 層を風洞測定部に作製し，表一1に示すように，高さ $H$ の $1 / 8$ の厚さの中空層を有する模型 24 種と，表一 2 に 示すように，高さの異なる矩形模型 13 種の周辺気流を 3 次元的に測定した。その結果, 中空層の設置位置とそ の周辺気流との関連に関して，次の結果を得た。ただし， 以下の結果は, アスペクト比 $(H / W)$ が 2 - 5 の矩形建 築物について得られるものである。

(1) 中空層を適切な位置に設けることにより, 建物周辺 の地表面近傍の風速増加域を低減させるこしができる。 最大の低減効果が期待できる設置位置は，おおむね地表 面から中空層の下端までの高さがほぼ建物の幅 $W$ と等 しい位置である。ただし，アスペクト比が 4 以上の場合 には，それ以上の高さであれば, 同程度の低减効果が期 
待できる。最適な位置に中空層を設けた状態では，アス ペクト比にかかわらず, 平均風速の最大值は $7 \sim 8 \%$ 減 少し, 風速増加域（建設に伴い平均風速が $10 \%$ 以上増 加する領域 $)$ の面積は，0.5 0.6 $(W \times D)$ 減少する。し たがって, 中空層の厚さ当たりの低減効果は, アスペク ト比が小さなものほよ゙大きい。例えば，アスペクト比が 2 の建物の最適な位置に中空層（厚さ $0.25 W$ ）を設け ることは, 平均風速の最大值に関しては, 高さを約 0.6 $W$ 分だけ低くすることと等価であり, 風速增加域の面 積に関しては, 高さを約 $0.4 W$ 分だけ低くすることと 等価である。

(2) 中空層を地表面に接して設け，ピロティ形式とした 場合, 風速増加域はもとの状態より増大する。増大の程 度はアスペクト比が小さなものほど大きい。例えば，ア スペクト比が 2 の建物にピロティを設けることは，平均 風速の最大值に関しては, 高さを約 $1.1 W$ 分高くする ことと等価であり，風速増加域の面積に関しては，高さ を約 $0.9 W$ 分だけ高くすることと等価である。

以上, 中空層の設置位置とその周辺気流の関連に関し ては，本報においてかなり明確にすることができた。し かしながら，中空層の厚さや中空層の両端に位置する側 壁の影響なよ゙については，いまだ明確ではない。これら 本報で残された課題については，現在すでに実験を継続 して実施しており，次報以下で順次報告する予定である。

\section{参考文献}

1）例えば，関根 毅，海野健一：市街地における建築物周 辺気流の立体的構造に関する研究 その 3 独立的建築物 模型周辺気流の性状について, 日本建築学会論文報告集, 第 247 号, pp. 111 117, 1976. 9

2）例えば, 亀井 勇, 丸田栄蔵：高層建築物周辺に生じる 強風領域の実験的研究（第 1 報 強風領域に関係する諸 パラメータの検討), 日本建築学会論文報告集, 第 232 号, pp. $101 \sim 107,1975.6$

3）例えば, 黒谷靖雄, 関根 毅: 矩形建築物周辺気流の 3 次元分布について, 第 11 回風工学シンポジウム論文集, pp. 149 154, 1990. 12

4）例えば, 内海康行, 村上周三, 小峯裕己：建物周辺の強 風に対するネットフェンスの防風効果に関する風洞実験 (その 2 ) ネットフェンスの設置角度, 配置形状と防風 効果の関係, 日本建築学会大会学術講演梗概集, 講演番
号 4126, 1980

5）勝田高司，村上周三，池田耕一，上原 清：建物周辺に 発生する強風ならびに防風垣による強風の遮蔽に関する 風洞実験 その 1. 単独模型の場合 建物周辺気流に関す る実験的研究 (VI)，日本建築学会論文報告集，第 233 号, pp. 121 132, 1975.7

6）黒谷靖雄, 関根 毅：傾斜壁面を有する建築物の周辺気 流, 日本建築学会計画系論文報告集，第 419 号，pp. 31 $\sim 38,1991.1$

7）黒谷靖雄, 関根 毅：コーナーカットを有する建築物の 周辺気流, 日本建築学会計画系論文報告集, 第 421 号, pp. $21 \sim 30,1991.3$

8）中村国雄ほか 4 名：建物形状による周辺気流変化に関す る実験的研究, 日本建築学会大会学術講演梗概集, 講演 番号 2157, 1976

9）片山忠久：建物周囲気流に関する基礎的研究（その 8) 模型隅角部の形状が強風領域におよぼす影響, 日本建築 学会関東支部研究報告集, 第 51 号, pp. 5 8, 1980

10）植松 康ほか 4 名：高層建物周辺の風環境に及ぼす建物 隅角部形状の影響に関する実験的研究, 第 11 回風工学 ンポジウム論文集，pp.143 148，1990. 12

11）関根 毅, 新上敏彦：市街地における建築物周辺気流に 関する実験的研究, 広島大学工学部研究報告, 第 29 巻, 第 2 号, pp. 187 194, 1981

12) Penwarden, A.D. and Wise, A.F.E. : Wind Environment around Buildings, Department of the Environment, Building Research Establishment, London, Her Majesty's Stationery Office, 1975

13）高木 猛, 岩佐義輝, 畑中公樹, 山口伸夫：高層建物の 周辺気流に関する研究ピロテイ部分の風速について, 日 本建築学会大会学術講演梗概集, 講演番号 2136,1974

14）亀井 勇, 丸田栄蔵, 卯月英夫, 薬袋寿紹: ピロティ内 を流れる風の性状に関する実験的研究, 日本建築学会大 会学術講演梗概集, 講演番号 2134, 1974

15）黒谷靖雄, 関根 毅: 建築物周辺気流を対象とする風洞 実験における閉塞効果, 日本建築学会計画系論文報告集, 第 415 号, pp. $1-8,1990.9$

16) Berman, S. : Estimating the Longitudinal Wind Spectrum Near the Ground, Qu. Jul. Roy. Met. Soc., vol. 91, pp. 302 316, 1965

17）風洞実験法研究会：建築物周辺気流の風洞実験法に関す る研究報告書, 日本建築センター, 1984.3

（1991年 2 月 10 日原稿受理，1992年２月19 日採用決定） 